\title{
The Improving Speaking Ability Of Esp Students Through Self-Assessment And Peer-Assessment
}

\author{
Hasnani', Muh. Hosni Mubarak ${ }^{2}$ \\ 1 Pendidikan Bahasa Inggris, Universitas Megarezky \\ Email: hasnani.helmy@gmail.com \\ 2 Kebidanan, Universitas Megarezky
}

\section{Artikel info}

Artikel history:

Received; 28-08-2019

Revised:29-08-2019

Accepted;14-10-2019
Abstract. Self-Peer-Assessment (SPA) is one of the learning methods that can be used to improve speaking ability in English Speaking ability is one of the important skills in English and it is very encouraging for students to learn, especially for students who use an ESP because it will be an added value in developing their capabilities. The purpose of this research is to explain the ability of students of ESP D3 Medical Laboratory Technology (TLM) at the Megarezky University through self-peer-assessment (SPA). This research is a Classroom Action Research (CAR), with planning for each class action research cycle carried out through four (4) stages which include: planning, implementing actions, observing/collecting data, and reflecting. Quantitative data collection techniques were obtained by tests (pre-test, interview, discussion, and post-test), as well as through observation, field notes and documentation in the teaching and learning process.

The results of this study indicate that the use of SEF assessment and peer assessment in cycle I was at $56.6 \%$, while in cycle II there was a significant increase of $96.6 \%$. This proved that the speaking ability of ESP students increased by using self assessment and peer assessment.

Abstrak.: Ketik abstrak bahasa indonesia. tidak boleh lebih dari 200 kata, dalam satu alinea tanpa acuan (referensi) tanpa singkatan/akronim, dan tanpa footnote. Abstrak ditulis bukan dalam bentuk matematis, pertanyaan, dan dugaan. Abstrak berisi: tujuan penelitian, metode penelitian, teknik analisis dan hasil penelitian. Diketik dengan font Times New Roman, spasi tunggal, dan dicetak miring. Self-Peer-Assessment (SPA) adalah salah satu metode pembelajaran yang dapat digunakan untuk meningkatkan kemampuan berbicara dalam bahasa Inggris. Kemampuan berbicara adalah salah satu keterampilan penting dalam bahasa Inggris dan sangat mendorong bagi siswa untuk belajar, terutama bagi siswa yang menggunakan ESP. karena akan menambah nilai dalam mengembangkan kemampuan mereka. Tujuan dari penelitian ini adalah untuk menjelaskan kemampuan mahasiswa Teknologi Laboratorium Medis ESP D3 (TLM) di Universitas Megarezky melalui penilaian sejawat (SPA). Penelitian ini adalah 
Penelitian Tindakan Kelas (PTK), dengan perencanaan untuk setiap siklus penelitian tindakan kelas dilakukan melalui empat (4) tahap yang meliputi: perencanaan, tindakan implementasi, mengamati/mengumpulkan data, dan refleksi. Teknik pengumpulan data kuantitatif diperoleh dengan tes (pre-test, wawancara, diskusi, dan post-test), serta melalui observasi, catatan lapangan dan dokumentasi dalam proses belajar mengajar. Hasil penelitian ini menunjukkan bahwa penggunaan penilaian mandiri dan penilaian sejawat pada siklus I adalah di $56,6 \%$, sedangkan pada siklus II ada peningkatan yang signifikan sebesar 96,6\%. Ini membuktikan bahwa kemampuan berbicara siswa ESP meningkat dengan menggunakan penilaian diri dan penilaian sejawat.

Keywords:

Speaking ability;

Self-Assessment;

Peer-Assessment;
Coresponden author: Email: xxxx@gmail.com

artikel dengan akses terbuka dibawah lisensi CC BY -4.0

\section{Background}

The spacing method is one of the most important things in the learning process, this will give significant results in learning outcomes. In the teaching and learning process, teachers should provide the right method for their students to become learning for students to learn, this will also be a strategy that can help students to develop their abilities as desired. Speaking ability is one of learning in English subjects, because speaking ability (speaking ability) is one indicator of increasing learning outcomes in the teaching-learning process.(Sadler \& Good, 2006).

In improving speaking skills, students majoring in English are already familiar with the ability to speak (speaking), but this is contrary to non-language students (ESP) so they ask for more effort with the right methods to improve them. A very common problem is in non-language students who are concerned about fear and also lack of confidence in themselves. Concern that is too excessive makes students inhibited in developing attachment to conversation (Banditvilai, 2016). They are afraid of wrong word order, wrong mention of excessive shame makes them not develop speaking skills. Students in the Megarezky University campus also solve the same problem in developing their skills in English, based on the learning experience of researchers at that campus, researchers classify research topics in English: the need to make conversation in conversation, low self-confidence and sense shame in English (Tarighat \& Khodabakhsh, 2016).

The research problem is as follows: "How to improve the speaking ability of ESP D3 TLM students by using self-assessment and peer assessment methods?. Objective of research to find out the improvement in speaking ability of ESP D3 TLM students by using self-assessment and peer-assessment methods. Significant of research can make a conceptual contribution to the 
enforcement of English evaluation/learning methods for ESP students, as well as to improve the competence of English language teachers to be more varied in the teaching and learning process to improve the speaking abilities of ESP students.

\section{Literature Review}

\section{Self-Assessment}

In self-assessment, students can make an assessment of themselves even though they are not in class, this provides convenience and flexibility for students to carry out self-assessments objectively. Whereas according to Boud self-assessment includes two elements namely; students make standards or criteria to be applied in the learning process and decide on the process of achieving these criteria or standards. However, in this evaluation aspects of honesty are given priority because students sometimes find it difficult to recognize or judge themselves subjectively.(Boud, 1992) Teachers must encourage students to show their self-evaluation results to people they trust, such as close friends and family. This will make it easier for students and teachers to find out the level of intelligence or understanding of students. In conducting selfassessment to check the development of the learning process, and is a reflection of the learning process for yourself (Biggs \& Tang, 1999). The development of teaching techniques using the self assessment method is a dynamic development in teaching. Some of the advantages of using the self-assessment method are:

a. Be a thorough and accurate student in the self-assessment process

b. Self-assessment activities can help students become realistic and critical of themselves can help improve their self-performance

c. Reduced teacher involvement in the implementation of self-assessment

d. Feedback from self-assessment can increase student morale in their learning process (Ross \& Bruce, 2007).

In conducting self-assessment, instructors should conduct intensive communication to students to introduce more carefully about self-assessment. It aims to provide students with a deep understanding of the benefits, responsibilities and outcomes they will get in conducting a self-assessment as habits of thinking that have a relationship between metacognitive and reflection.

Peer-Assessment is another model of formative assessment where the assessment process is carried out by peers. This form of assessment is somewhat different from before because students will provide an objective assessment of their peers. Assessment conducted using the peer-assessment method is an improvement in improving communication for students, because it will have a very good impact that can be felt indirectly for improving communication skills.(Tarighat \& Khodabakhsh, 2016) 
Meanwhile, the use of peer-assessment in the learning process requires the introduction of habituation to students, because the assessment process will involve two parties. It aims to obtain an objective value from them. However, before using peer assessment in teaching, lecturers should discuss and inform students about the use and achievements of peer assessment (Khamkhien, 2010). Teachers must also give good direction to students not to be subjective in conducting peer assessment and give great confidence to students in carrying out their duties, it aims to make students feel full responsibility in assessing their friend. Criticism skills are also one of the important things in conducting an assessment, because it is because students will criticize not only themselves but they will also do it to others. In addition, the instructor also has an important task in conducting the feedback method because of that it will give birth to a good critical thinking technique from students. Nicol and Macfarlane-Dik concluded that seven of the best feedback methods are:

a. Feedback (feedback) will help in doing a good performance

b. Feedback fosters student development in the learning process self and peer assessment

c. Feedback can convey good information about pain student learning.

d. Feedback also provides good communication opportunities between teachers and peers in talking / communicating with each other

e. Feedback also increases positive motivation (McMaster, Fuchs, \& Fuchs, 2007).

\section{Methodology}

This type of research is descriptive quantitative using a Classroom Action Research (CAR) study or Classroom Action Research.(Bisse, 2017) Classroom action research is a form of systematic reflective study by action actors to improve the conditions of learning undertake.(Irmawati, 2012). According to Kemmis and Taggart, which is spiral from one cycle to the next. Each cycle includes planning, action, observation, and reflection (Arikunto, 2006a).

This research was located at D3 Medical Laboratory Technology, Megarezky University. Research is from April to November 2019. The subjects of this study were TLM D3 Students of secong semester of 2018/2019 Academic Year. The class action research design that will be carried out consists of two or more cycles described as follows.

Planning Phase

a) Develop a semester learning plan that is consistent with the lecture material to be taught.

b) Develop and develop a learning plan

c) The lecturer makes observation guidance instruments for observe learning conditions in the classroom during the learning process takes place. 
d) Making the final test instruments of cycles I and II to determine student learning outcomes after the self-peer-assessment method is applied in the teaching and learning process (Irmawati, 2012).

Observation Stage

At this stage there are two treatments namely observation and evaluation. Implementation of the observation phase of student activities and the activities of lecturers teaching and learning process used observation sheets. The implementation of the evaluation provides a test of learning outcomes carried out at the end of each cycle with the aim of knowing the improvement in learning outcomes after it is applied.

\section{Reflection Stage}

At this stage the researchers reflect on the results achieved in the observation and evaluation stages collected and then performed analysis and reflection. Reflection is intended to see whether the plan has been implemented optimally or needs to be improved. The results of the first cycle of analysis are used as a reference for planning to the next cycle where aspects that are considered good are maintained, while the shortcomings are considered and revised in the next cycle (Arikunto, 2006b).

Data Collection Techniques

The data collection techniques used in this study are:

Observation

Data about the activities of teachers and students in the teaching and learning process during the action taken is taken by using observations both directly and indirectly with several indicators observed. The Multiple Choice \& Essay tests are used to retrieve data in each cycle to get data about the learning outcomes achieved by students after the self and peer assessment methods are applied.

Data Analysis Techniques

Student learning outcomes data in the form of tests will be analyzed using scores based on benchmark reference assessments, calculated based on the maximum score possible by students. Values obtained are grouped into five categories: very good, good, enough, less and very less. Criteria which

\section{Findings and Discussion}

The classroom action research was carried out at DIII TLM, Megarezky University on Antang Raya Street No. 48 Makassar. The second semester is the subject of research in conducting classroom action research (CAR) because learning outcomes are in English. The subjects of this study, namely 30 students, are consisting of 3 men and 27 women. This research 
was conducted in 2 cycles, each cycle consisting of three meetings, and each cycle carried out tests or evaluation at the end of the cycle. The results of the research showed each cycle in applying Self-Assessment and Peer-Assessment in learning English in the Second Semester of the DII TLM of Megarezky University as follows;

a. Cycle Planning Phase I

In the first cycle, based on the results of discussion with observation, it was found that the research on:

The first meeting, it was held on Thursday 9 May 2019, at the first meeting, the lecturer began the learning by saying greetings and briefly introducing themselves to students. The lecturer asks the students to take part in the teaching and learning process in speaking class as well as having a brief discussion about their experiences, impressions and feeling in English class.

However, this is not used by the lecturer as a barrier to achieving the goals to be completed, namely, to activate students in learning and improve student learning outcomes. Thus lecturers always provide stimuli in the form of questions related to the subject matter but attract the attention of students. The method used by lecturers to attract the attention of students by linking subject matter with the conditions that students often encounter in their daily lives. One of the questions posed by lecturers that is of sufficient interest to students is when lecturers ask students' opinions about what they often encounter in their daily lives.

The lecturer efforts to attract the attention of students to show positive change where students have occurred to venture in expressing their opinions about what they encounter in their daily lives.

The second meeting held on Monday, 3 June 2019, at the previous session, students were still doubtful when the lecturer began asking questions. During the learning process of this second meeting, the lecturer always provides stimulation and practice to students by asking questions related to their daily activities. After the learning model applied by the lecturers is by applying self-assessment and peer assessment in learning English the ability of students to express opinions becomes more enthusiastic because they can think without feeling ashamed of their lecturers and friends.

Although in its application, the lecturer always faces obstacles, it is an impediment to continue implementing the initial plan that has become the primary goal. One of the challenges faced by lecturers is the allocation of time which gives less space for students to find data either through books or from the mass media. However, lecturers still try as much as possible to streamline learning time so that the learning process can run smoothly. And Alhamdulillah, 
students gave a reasonably good response to the learning system implemented by the lecturer during the learning process.

The third meeting was held on Monday, 10 June 2019. The beginning of the lecturer learning gave apperception, motivation, and conveyed material indicators to be explained and checked the readiness of students in preparing learning activities. The lecturer divides the group, and each group consists of 4 students; each group gets the material given to students to be discussed with their group friends. After discussing with their group friends, each student will appear to tell the contents of the material they get, and their group friends will give an assessment related to the speaking performance of their group friends, according to the concept of self-assessment and peer assessment.

The fouth meeting is conducted as the final test of Cycle I. Before the questionnaire are distributed to students, the lecturer provides motivation to students and assures students to answer the questions by giving multiple-choice and essay questions. After that, the question sheets distributed to the students, and the students started working on the subjects.

From the results of the discussion carried out together, it turns out there are still many students who have not been able to express their opinions adequately. Therefore, the lecturer gives direction to students to better prepare themselves in following the learning process, further action is held, namely in cycle II.

1) Learning Cycle I Test Results

Data about student learning outcomes in the first cycle is used to determine the value of student learning outcomes after the activities of the first cycle of action by evaluating students. From result research known that there are no students who have grades in the very poor category, 13 students are less 43.3\%, 10 students (66.6\%) are in the moderate category and 7 students (23.3\%) are in a good category.

the completeness of learning outcomes show that 20 students who get 0-69 with a percentage of $66.6 \%$ are incomplete and while 10 students who get 70-100 with a percentage of $33.3 \%$ who complete. Therefore, the lecturer gives direction to the students to better prepare themselves in following the learning process, further action is held, namely in the second cycle.

b. Implementation of Cycle II

In Cycle II based on the results of discussion with observation it was found that the research in Cycle II was as follows:

The first meeting in the second cycle was held on Monday 17 June 2019. In the first meeting of the second cycle, the students looked much more prepared compared to the last cycle I meeting, this was proven by the increasingly diverse comments and opinions of the students they expressed during the learning process. This is because the exercises make them more 
accustomed, because learning requires practice, by means of: retelling, and reviewing so that lessons can be more easily understood and lessons that have not been mastered will be easier to understand. One of the questions asked by lecturers to students is to give a conclusion about their understanding of assessment based English Learning; both independent assessments or peers.

The second meeting on the second cycle was held on Wednesday, June 20, 2019. At this meeting, the lecturer gave material about Family and asked their partners to explain their partner's assessment in English. In self-assessment, students are required to believe in themselves so that they can judge themselves objectively. Whereas in peer assessment, couples in their groups will provide an assessment in their friend's speaking performance, and will be exposed openly from their assessment so that the evaluation process also occurs objectively. At the second meeting of the second cycle gave evidence that the lecturer succeeded in arousing the interest and enthusiasm of student learning, this can be seen from the readiness of the Students when attending the English learning process carefully.

Third Meeting

This third meeting was held on Monday June 24, 2019, at this meeting was the last meeting of a series of five previous meetings. The lecturer hopes that the evaluation conducted at the end of the second cycle meeting shows the achievement of maximum results. Seen from the series of five previous meetings, it showed a positive change where at the beginning of the meeting Students were very unenthusiastic and there were even students who were silent in participating in learning English, but after the lecturer applied the self assessment and peer assessment models (peer assessment) ) make students feel interested and excited in participating in learning English. This also influences students' speaking ability.

The fourth in the second cycle evaluation was carried out or repeated as the final test of the second cycle. Conducting evaluation in this second cycle, the lecturer divides students into groups and asks them to video students' English Speaking so that they will be assessed objectively; both self-assessment and peer assessment.

1) Cycle Learning Test Results II

Data about student learning outcomes in cycle II is used to determine the increase in student grades between cycle I and the value of cycle II. Data on learning outcomes were obtained after the second cycle of action activities by evaluating students.

\section{Discussion}

The discussion is focused on the activities of lecturers and student activities in the application of assessment-based learning; self assessment and peer assessment. In selfassessment the use of self-assessment to change the previous assessment, the researcher first 
asks second semester students to record the way they speak English by retelling the story material provided. Then the researchers provide a recording of the story for their use in selfassessment. The objective of this paper is to review the pronunciation and fluency of speech. Specifically researchers want to encourage them to challenge themselves to find the mistakes they make in their pronunciation, be familiar with English expressions, not dialed English regional languages, and to learn what structures are valid and valuable from this kind of pattern.

The Use of peer assessment for students will recognize knowledge assessment easily, the assessment process tends to be new. Researchers can positively motivate student researchers. For example, participation in study groups, group presentations about background information related to the text. When students are asked to rate colleagues and are independent, students use table 3 and table 4 in the appendix, which is modified from Roach to assess other students or themselves presentations. They can give a score (score of 100) according to their presentation. The grades students give themselves are generally higher than I expected.

Student learning approaches in some parts have changed a lot. When they search for information related to the text, discuss material in groups, it is clear that students have an active exchange of ideas, try to use deep learning, form research ideas that are more productive and inspired. They build the material they have, not the material given to them.

Based on the research that has been carried out, the acquisition of English language learning outcomes of students from the two research cycles increased to achieve the indicators of success that have been established shows that the results of English learning students have increased significantly. The use of self assessment and peer assessment learning models increases student learning outcomes that were initially low, can be improved after learning English based on self assessment and peer assessment.

\section{Conclusion and Suggestion}

During this research there were many cases that found by the researcher which made the students' speaking ability were low. Those problems were caused by many factors such as: firstly the teacher's teaching method was monotonous and it affected the students' motivation to study as the result they got difficult to express their ideas. Secondly they students were low of vocabularies. Based on those cases, the researcher intended to improve the students' speaking ability by used self-assessment and peer-assessment. After implementing the Picture Stories method, the researcher found that students' speaking ability was improved.

The implementation of self-assessment and peer-assessment could improve the speaking ability of students as the result the research. The researcher hoped it will be useful for the English teachers, the students, the institution and the other researchers. For teachers and students, the result of this research could be the interesting method that the teacher can use to 
improving the teaching and learning process, it would be interesting method to assess the speaking of the students and it believed that the students will be attractive in the class. For the researcher, there are many elements positive and negative in this study that the other researcher can use as a new insight or knowledge. Further the researcher hoped this research can be a source for the other researcher in teaching and learning process and the research could be one of the source information for the institution.

\section{Acknowledment}

A deeply thank you to the government, especially Ministry of Research, Technology and Higher Education of the Republic of Indonesia for providing the opportunity and funding all research activities in the Beginner Lecturer Research (PDP) scheme to the researchers.

\section{Refenrences}

Arikunto, S. (2006a). Prosedur Penelitian Tindakan Kelas. Bumi Aksara. https://doi.org/10.1362/026725701323366836

Arikunto, S. (2006b). PROSEDUR PENELITIAN TINDAKAN KELAS. Bumi Aksara.

Banditvilai, C. (2016). Enhancing students' language skills through blended learning. Electronic Journal of E-Learning.

Biggs, J., \& Tang, C. (1999). Assessing for learning quality: II. Practice. Teaching for Quality Learning at University. https://doi.org/10.1097/00005176-200304000-00028

Bisse, N. (2017). Utility of self access materials in second language learning for autonomous learners. Asian EFL Journal.

Boud, D. (1992). The Use of Self-assessment Schedules in Negotiated Learning. Studies in Higher Education. https://doi.org/10.1080/03075079212331382657

Irmawati, N. D. (2012). Communicative approach: An alternative method used in improving students' academic reading achievement. English Language Teaching. https://doi.org/10.5539/elt.v5n7p90

Khamkhien, A. (2010). Journal of Language Teaching and Research. Thai Learners' English Pronunciation Competence: Lesson Learned from Word Stress Assignment. https://doi.org/10.4304

McMaster, K. L., Fuchs, D., \& Fuchs, L. S. (2007). Promises and limitations of peer-assisted learning strategies in reading. Learning Disabilities: A Contemporary Journal.

Ross, J. A., \& Bruce, C. D. (2007). Teacher self-assessment: A mechanism for facilitating professional growth. Teaching and Teacher Education. https://doi.org/10.1016/j.tate.2006.04.035

Sadler, P. M., \& Good, E. (2006). The impact of self- And peer-grading on student learning. Educational Assessment. https://doi.org/10.1207/s15326977ea1101_1

Tarighat, S., \& Khodabakhsh, S. (2016). Mobile-Assisted Language Assessment: Assessing speaking. Computers in Human Behavior. https://doi.org/10.1016/j.chb.2016.07.014 